Bangladesh J. Bot. 41(2): 143-148, 2012 (December)

\title{
MORPHOMETRIC ANALYSIS OF DESMODIUM DESV. IN BANGLADESH
}

\author{
Md Zahidur Rahman AND M Oliur Rahman* \\ Department of Botany, University of Dhaka, Dhaka-1000, Bangladesh \\ Key words: Desmodium, Morphometric analysis, Cluster analysis, UPGMA, Taxonomy, \\ Bangladesh
}

\begin{abstract}
Phenetic analysis based on morphological characters is presented for 14 species of Desmodium Desv. in Bangladesh. This study examines patterns of morphological similarity and variation within Desmodium using 36 floral and vegetative characters. $D$. heterophyllum shows highest similarity with $D$. triflorum among the species employed. UPGMA dendrogram is constructed based on cluster analysis which reveals two major clusters, the first of which consists of seven species while the second cluster comprises six species, and $D$. microphyllum is found far from all other species. The presence of winged petioles distinguishes $D$. alatum and $D$. auriculatum from the other species. The present study shows the application of morphometric analysis for understanding the phenetic relationships among the species of Desmodium.
\end{abstract}

\section{Introduction}

The genus Desmodium Desv. (Fabaceae) consists of approximately 280 species mostly distributed in subtropical and tropical regions (Puhua and Ohashi 2010). Very recently Hyde et al. (2012) report the distribution of 450 species of Desmodium in warm regions, especially in East Asia, Brazil and Mexico. Desmodium and its allied genera are mainly native to the tropics and subtropics. Ohashi (1973) records two centers of geographic distribution and differentiation, South-east Asia and Mexico. Williams (1983) states that South-east Asia is a centre of legume diversity, while Schubert (1980) considers Mexico and Brazil as the centers of diversity of Desmodium. The genus Desmodium can be recognized by uni- or tri-foliolate leaves, simple raceme or panicle inflorescence and distinctly jointed pods. The systematics of the genus Desmodium is confusing and not yet resolved completely. For example, several species of Desmodium have been transferred to the genera Dendrolobium, Hylodesmum, Lespedeza and Phyllodium, and some species of other genera such as Hedysarum and Uraria are still included to Desmodium (Puhua et al. 2010). Ohashi and Mill (2000) based on morphological characteristics, proposed to split 14 species out of Desmodium and placed them in the newly described genus Hylodesmum. Although several taxonomic treatments on the genus Desmodium were carried out based on morphological characters (Liu and Chang 1962, Ohashi 1973, Pedley and Rudd 1996, Shaheeen 2008), however, in Bangladesh no detailed study has been completed on this important and complicated genus, except listing its few species (Prain 1903, Khan et al. 1996, Ahmed et al. 2009).

Morphometric is the study of covariances between patterns of morphological variation and patterns of variation in other associated or causal variables (Bookstein 1991). Morphometric methods can be instrumental in discovering, documenting and analyzing morphological character and character states, and have become important tools for understanding similarities and inferring relationships in different groups of plants. Morphometric and cladistic analyses based on morphological characters have been carried out in a number of genera and families (Michelangeli 2000, Roalson et al. 2002, Li and Conran 2003, Sonibare et al. 2004, Gomes-da-Silva et al. 2012).

*Author for correspondence: <dr_oliur@yahoo.com>. 
Despite morphometric studies were carried out in some legume genera (Chandler and Crisp 1998, de La Estrella et al. 2009, Soladoye et al. 2010), there has been no such study on Desmodium so far. The aims of this study are to examine the patterns of morphological variation and phenetic relationships in the genus Desmodium in Bangladesh.

\section{Materials and Methods}

Fourteen species of Desmodium viz., D. alatum, D. auriculatum, D. concinnum, $D$. dichotomum, $D$. gangeticum, $D$. heterocarpon, $D$. heterophyllum, $D$. laxiflorum, $D$. microphyllum, $D$. oblongum, $D$. sequax, $D$. styracifolium, $D$. triflorum and $D$. velutinum were employed in the present study. Among them nine species along with representative specimens have been mentioned in Table 1 . For the remaining five species, namely $D$. concinnum, $D$. dichotomum, $D$. microphyllum, $D$. sequax and $D$. auriculatum neither herbarium nor living specimens were available; consequently character states for these taxa were selected from the relevant literature (Baker 1876, Liu and Chang 1962, Schubert 1980, Pedley and Rudd 1996, Ahmed et al. 2009). Both fresh materials collected from different parts of the country, and herbarium specimens deposited in the herbaria DUSH (Dhaka University Salar Khan Herbarium), DACB (Bangladesh National Herbarium), HCU (Chittagong University Herbarium) and BFRIH (Bangladesh Forest Research Institute Herbarium) were examined for this study (Table 1).

Table 1. List of nine Desmodium species employed in the present study with their sources.

\begin{tabular}{|c|c|c|}
\hline No. & Species & Representative specimens \\
\hline 1. & Desmodium alatum DC. & $\begin{array}{l}\text { Zahid } 73 \text { (DUSH); M.S. Khan K } 69 \text { (DUSH); M.A. Rahman } \\
\text { \& M. Hossain } 2389 \text { (HCU). }\end{array}$ \\
\hline 2. & D. gangeticum (L.) DC. & $\begin{array}{l}\text { Zahid } 85 \text { (DUSH); Khan \& Huq K } 6177 \text { (DACB); M.A. } \\
\text { Rahman } 571 \text { (HCU). }\end{array}$ \\
\hline 3. & D. heterocarpon (L.) DC. & $\begin{array}{l}\text { Zahid } 91 \text { (DUSH); M.S. Khan K } 7113 \text { (DACB); M.S. Islam } \\
125 \text { (HCU). }\end{array}$ \\
\hline 4. & D. heterophyllum (Willd.) DC. & $\begin{array}{l}\text { Zahid } 74 \text { (DUSH); Hassan } 132 \text { (DUSH); M.K. Alam W } 14 \\
\text { (BFRIH). }\end{array}$ \\
\hline 5. & D. laxiflorum DC. & $\begin{array}{l}\text { M.S. Khan K } 6717 \text { (DACB); Huq } 8558 \text { (DACB); M.S. Khan } \\
\text { K } 7867 \text { (DACB). }\end{array}$ \\
\hline 6. & D. oblongum Wall. ex Benth. & $\begin{array}{l}\text { M.S. Khan K } 6441 \text { (DACB); M. Mohiuddin \& Md. Mezanul } \\
\text { Huq } 7537 \text { (BFRIH). }\end{array}$ \\
\hline 7. & D. styracifolium (Osbeck) Merr. & $\begin{array}{l}\text { Zahid } 27 \text { (DUSH); M.S. Khan K } 3374 \text { (DACB); Huq } 9013 \\
\text { (DACB). }\end{array}$ \\
\hline 8. & D. triflorum (L.) DC. & $\begin{array}{l}\text { Zahid } 63 \text { (DUSH); M.S. Khan K } 6567 \text { (DACB); M.A. } \\
\text { Rahman } 4671 \text { (HCU). }\end{array}$ \\
\hline 9. & D. velutinum (Willd.) DC. & M.S. Khan K 6577 (DACB); M.K. Alam 4803 (BFRIH). \\
\hline
\end{tabular}

A data matrix based on the coded binary states of characters was used in the analysis. Cluster analyses using the UPGMA method (unweighted pair-group method with arithmetical averages) were carried out (Sneath and Sokal 1973), from which a dendogram representing the phenetic relationships among the species was constructed. All analyses were carried out using the software Statistica (version 9). 


\section{Results and Discussion}

Thirty six floral and vegetative characters were identified and examined. The characters and their binary states used in the morphometric analyses of 14 species of Desmodium are depicted in Table 2.

Table 2. Morphological characters and their binary character states used for morphometric analysis of Desmodium.

\begin{tabular}{|c|c|c|}
\hline No. & Characters attributes & Character states \\
\hline 1. & Habit & Herb (0); Shrub (1). \\
\hline 2. & Stem & Glabrous (0); Hairy (1). \\
\hline 3. & Triquetrous branch & Absent (0); Present (1). \\
\hline 4. & Leaf & Uni-foliolate (0); Tri-foliolate (1). \\
\hline 5. & Leaf attachment & Opposite (0); Alternate (1). \\
\hline 6. & Petiole length & $>2.5 \mathrm{~cm}(0) ; 0.1-2.5 \mathrm{~cm}(1)$. \\
\hline 7. & Petiole outline & Slender (0); Cylindrical (1). \\
\hline 8. & Winged petiole & Absent (0); Present (1). \\
\hline 9. & Laminar shape & Ovate to lanceolate (0); Obovate to oblong (1). \\
\hline 10. & Base angle & Obtuse (0); Acute (1). \\
\hline 11. & Apex angle & Obtuse (0); Acute (1). \\
\hline 12. & Apex shape & Obtuse or emerginate (0); Acute (1). \\
\hline 13. & Base shape & Obtuse or rounded (0); Attenuate (1). \\
\hline 14. & Leaf surface & Glabrous (0); Hairy (1). \\
\hline 15. & Leaf margin & Undulate (0); Entire (1). \\
\hline 16. & Vein lobation & Absent (0); Present (1). \\
\hline 17. & Stipule & Ovate or lanceolate (0); Triangular (1). \\
\hline 18. & Flowers & Solitary (0); Fasciculated (1). \\
\hline 19. & Inflorescence & Terminal (0); Axillary and terminal (1). \\
\hline 20. & Length of inflorescence & $5-30 \mathrm{~cm} \mathrm{(0);} \mathrm{>} 30 \mathrm{~cm}(1)$. \\
\hline 21. & Corolla colour & Whitish to yellow (0); Pink to purple (1). \\
\hline 22. & Pedicel length & 15-20 mm (0); 1-12 mm (1). \\
\hline 23. & Calyx shape & Tubular or funnel shaped (0); Campanulate (1). \\
\hline 24. & Calyx teeth & Ovate or lanceolate (0); Triangular (1). \\
\hline 25. & Calyx lobe & 5-lobed (0); 4-lobed (1). \\
\hline 26. & Bract & Absent (0); Present (1). \\
\hline 27. & Shape of bract & Ovate (0); Linear to lanceolate (1). \\
\hline 28. & Secondary bract & Absent (0); Present (1). \\
\hline 29. & Bracteole & Absent (0); Present (1). \\
\hline 30. & Stamens & Monadelphous (0); Diadelphous (1). \\
\hline 31. & Ovary & Glabrous (0); Pubescent (1). \\
\hline 32. & Pod shape & Straight or linear (0); Falcate (1). \\
\hline 33. & Indent of pod & One side (0); Both sides (1). \\
\hline 34. & Surface of pod & Glabrous (0); Hairy (1). \\
\hline 35. & Joint of pod & 2-4 joints (0); 6-10 joints (1). \\
\hline 36. & Number of seeds/pod & 5-10 seeds (0); 2-4 seeds (1). \\
\hline
\end{tabular}


The morphometric analysis reveals the extent of phenetic relationships among 14 species of Desmodium. Two major clusters are found in the UPGMA dendrogram constructed through cluster analysis. The first cluster consists of seven species, viz., D. alatum, $D$. auriculatum, $D$. sequax, $D$. velutinum, $D$. gangeticum, $D$. laxiflorum and $D$. oblongum, while the second cluster comprises six species, i.e., $D$. concinnum, $D$. styracifolium, $D$. dichotomum, $D$. heterocarpon, $D$. heterophyllum and D. triflorum. D. microphyllum is found to be most far from all other species (Fig. 1).

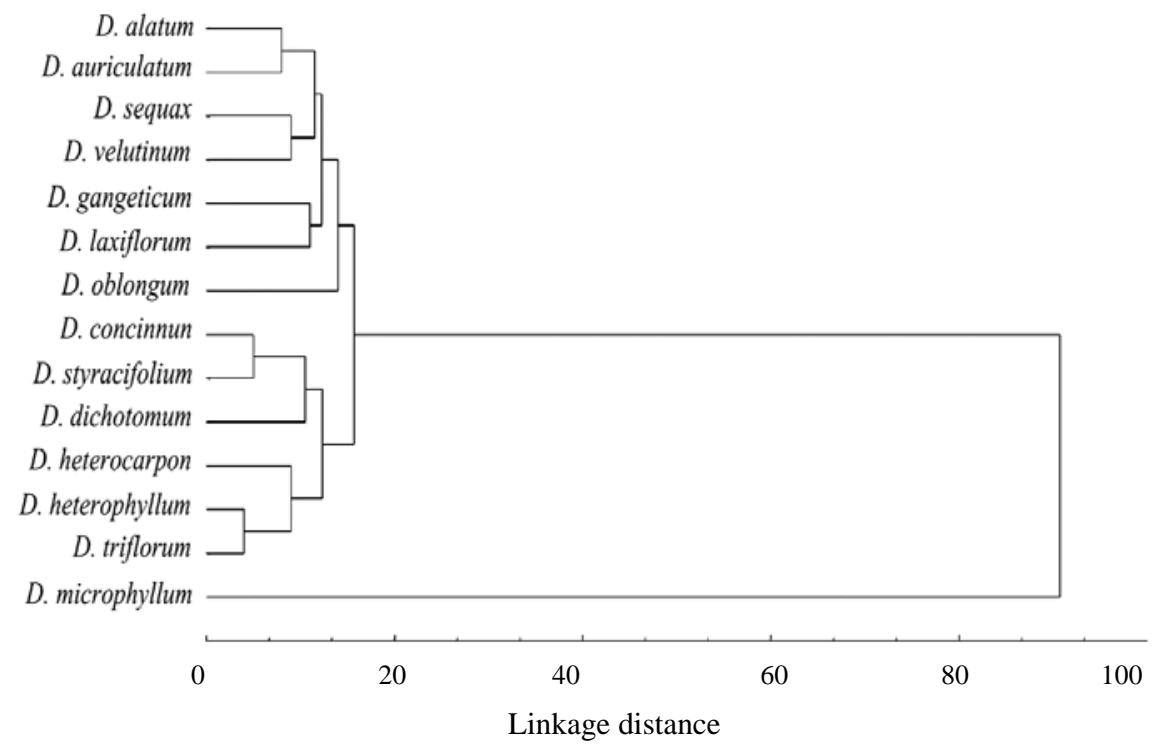

Fig. 1. UPGMA dendrogram showing the relationships among Desmodium species based on morphological characters.

In the first cluster $D$. alatum is grouped with $D$. auriculatum, $D$. sequax with $D$. velutinum and $D$. gangeticum with $D$. laxiflorum indicating that the members of each of these three groups are more close to each other than they are to the members of other groups (Fig. 1). The closeness between $D$. alatum and $D$. auriculatum is supported by their lanceolate leaves and presence of wings on the petioles. The close association between $D$. sequax and $D$. velutinum is supported by their 4-lobed campanulate calyx and moniliform pods. This finding is consistent with pollen morphology of these species wherein the pollen is without microperforation, the endoapertures are lalongate, the tectum is finely reticulate and the simple columellae have no granular interstitia (Chen and Huang 1993). The sub-cluster of $D$. gangeticum and $D$. laxiflorum is attested by the characters of hairy stem, absence of bracteoles, pubescent calyx and incurved style.

In the second major cluster two distinct sub-clusters have been found. The first one consists of $D$. concinnum, $D$. styracifolium and $D$. dichotomum. The common characters shared by these species include rounded leaf apex, diadelphous stamens and capitate stigma. In this sub-cluster $D$. concinnum and $D$. styracifolium are found to be more close to each other than they are to $D$. dichotomum. The close relationship between $D$. concinnum and $D$. styracifolium is evidenced by their axillary and terminal inflorescence, pink corolla and pubescent ovary. $D$. heterocarpon, $D$. heterophyllum and $D$. triflorum form another sub-cluster and their close association is supported 
by presence of tri-foliolate leaf, obovate to oblong lamina, hairy stem and lobed venation. Within this sub-cluster $D$. heterophyllum and $D$. triflorum are found to share the highest similarity which is supported by the characters: prostrate herbs, leaves tri-foliolate, leaflets chartaceous, terminal leaflet larger than lateral leaflets, stipules lanceolate, primary bracts ovate, acuminate, flower solitary and standard petal obovate. This finding is congruent with Chen and Huang (1993) who placed $D$. heterophyllum and $D$. triflorum in the same group and demonstrated that the pollens of these species are semi-angular in polar view, with thick, psilate tectum, reduced columella and substituted with granular interstitia. Our result is also supported by anatomical data (unpublished). In the dendrogram, D. microphyllum has been found morphologically most distant from all other species investigated in this study.

Finally, it is concluded that the morphometric analysis could be used for understanding the phenetic relationships among different species of Desmodium. Use of more taxa and additional tools would help for better understanding of systematics and relationships of the genus Desmodium.

\section{Acknowledgements}

The authors gratefully acknowledge the Centre for Advanced Studies and Research in Biological Sciences, University of Dhaka for partial financial support to conduct this study. They thank the authorities of the following herbaria for allowing to use their herbarium specimens and library facilities: DACB, HCU and BFRIH. Authors are thankful to Prof. Md. Abul Hassan and Prof. Momtaz Begum of the Department of Botany, University of Dhaka for their cooperation during the course of this study. Thanks are due also to Dr. Mohammad Nurul Islam of the same department for his cooperation during analysis of the data.

\section{References}

Ahmed ZU, Hassan MA, Begum ZNT, Khondker M, Kabir SMH, Ahmed M, Ahmed ATA, Rahman AKA and Haque EU (Eds) 2009. Encyclopedia of Flora and Fauna of Bangladesh, Vol. 8. Angiosprems: Dicotyledons (Fabaceae-Lythraceae). Asiatic Society of Bangladesh, Dhaka. pp. 73-87.

Baker JG 1876. Fabaceae. In: Hooker JD (Ed.), Flora of British India 2. L. Reeve \& Co. Ltd. England. pp. 161-175.

Bookstein FL 1991. Morphometric tools for landmark data: Geometry and biology. Cambridge University Press.

Chandler GT and Crisp MD 1998. Morphometric and phylogenetic analysis of the Daviesia ulicifolia complex (Fabaceae, Mirbelieae). Plant Syst. Evol. 209(1-2): 93-122.

Chen S-J and Huang T-C 1993. Pollen morphology of the tribe Desmodieae (Leguminosae) in Taiwan. Taiwania 38: 67-89.

de La Estrella M, Aedo C and Velayos M 2009. A morphometric analysis of Daniellia (Fabaceae Caesalpinioideae). Botanical J. Linn. Soc. 159(2): 268-279.

Gomes-da-Silva J, da Costa Vargens FA, de Oliveira Arruda RC and da Costa AF 2012. A morphological cladistic analysis of the Vriesea corcovadensis group (Bromeliaceae : Tillandsiodeae), with anatomical descriptions: new evidence of the non-monophyly of the genus. Systematic Botany 37(3): 641-654.

Hyde MA, Wursten BT and Ballings P 2012. Flora of Zimbabwe. Genus page Desmodium. http://www.zimbabweflora.co.zw/speciesdata/genus.php?genus_id=744, retrieved 22 September, 2012.

Khan MS, Khatun BMR and Rahman MM 1996. A preliminary account of legume diversity in Bangladesh. Bangladesh J. Plant Taxon. 3(1): 1-33.

Li J and Conran JG 2003. Phylogenetic relationships in Magnoliaceae subfam. Magnolioideae: A morphological cladistic analysis. Plant Syst. Evol. 242: 33-47.

Liu TS and Chang CC 1962. On the Taiwan species of Desmodium. Taiwania 8: 67-126. 
Michelangeli FA 2000. A cladistic analysis of the genus Tococa (Melastomataceae) based on morphological data. Systematic Botany 25(2): 211-234.

Ohashi H 1973. The Asiatic species of Desmodium and its allied genera (Leguminosae) Gingoana No. 1: 1138.

Ohashi H and Mill RR 2000. Hylodesmum, a new name for Podocarpium (Leguminosae). Edinburgh J. Bot. 57: 171-188.

Pedley L and Rudd VE 1996. Fabaceae, Tribe Desmodieae. In: Dassanayake MD and Clayton WD (Eds), Flora of Ceylon. Vol. 10. Oxford \& IBH publishing Co. Pvt. Ltd., New Delhi. pp. 149-198.

Prain D 1903. Bengal Plants. Vol. 1. Botanical Survey of India. pp. 301-305.

Puhua H and Ohashi H 2010. Desmodium Desv. In: Wu ZY, Raven PH and Hong DY (Eds), Flora of China. Vol. 10 (Fabaceae). Science Press, Beijing, and Missouri Botanical Garden Press, St. Louis. pp. 268278.

Puhua H, Ohashi H, Iokawa Y and Nemoto T 2010. Tribe Desmodieae. In: Wu ZY, Raven PH and Hong DY (Eds), Flora of China. Vol. 10 (Fabaceae). Science Press, Beijing, and Missouri Botanical Garden Press, St. Louis. pp. 262-311.

Roalson EH, Senters AE, Skog LE and Zimmer EA 2002. A morphological cladistic analysis of the Neotropical flowering plant genus Gasteranthus (Gesneriaceae). Systematic Botany 27(3): 573-591.

Schubert BG 1980. Flora of Panama. Part V, Fascicle 5. Family 83. Leguminosae, Subfamily Papilionoidae (Conclusion). 18. Desmodium. Ann. Miss. Bot. Gard. 67: 622-662.

Shaheen ASM 2008. Morphological and anatomical investigation in Desmodium tortuosum (SW.) DC. (Fabaceae): A new addition to the Egyptian flora. Bangladesh J. Plant Taxon. 15(1): 21-29.

Sneath PHA and Sokal RR 1973. Numerical Taxonomy. W.H. Freeman and Co. San Francisco, California

Soladoye MO, Onakoya MA, Chukwuma EC and Sonibare MA 2010. Morphometric study of the genus Senna Mill. in south-western Nigeria. African J. Plant Sci. 4(3): 44-52.

Sonibare MA, Jayeola AA and Egunyomi A 2004. A morphometric analysis of the genus Ficus Linn. (Moraceae). African J. Biotechnol. 3(4): 229-235.

Williams RJ 1983. Tropical Legumes. In: McIvor JG and Bray RA (Eds), Genetic resources of forage plants. CSIRO, Melbourne, Australia. pp. 17-31. 